\title{
Bio-agronomic Evaluation of Old and Modern Wheat, Spelt and Emmer Genotypes for Low-input Farming in Mediterranean Environment
}

\author{
Pasquale De Vita ${ }^{*}$, Anna Maria Mastrangelo ${ }^{1}$, Pasquale Codianni $^{1}$, Michele Fornara ${ }^{2}$, \\ Massimo Palumbo ${ }^{3}$, Luigi Cattivelli ${ }^{1}$ \\ ${ }^{1} C R A$ Centro di ricerca per la cerealicoltura \\ S.S. $16 \mathrm{~km}$ 675, 71100 Foggia, Italy \\ ${ }^{2}$ CRA Unità di ricerca per la valorizzazione qualitativa dei cereali \\ Via Cassia 176, 00191 Roma, Italy \\ ${ }^{3}$ CRA Ex Istituto sperimentale per la cerealicoltura - Sezione di Catania \\ Via Varese 43, 95123 Catania, Italy
}

Received: 21 May 2006. Accepted: 18 December 2006.

\begin{abstract}
Abbreviations: Heading date (HD); Plant height (PH); Grain yield (GY); Grain protein yield (GPY); Thousand ker-
\end{abstract} nel weight (TKW); Test weight (TW); Grain protein content (PC); Dry gluten (GC) content.

\begin{abstract}
Low-input cropping systems are characterised by the reduction of pesticides and chemical fertilizers and, often, by the use of old cultivars to realize sustainable crop production which can easily integrate in the European Union agricultural subsidies. Market prices and environmental concerns favour low-input wheat production systems, nevertheless protein standards become particularly difficult to achieve in these conditions due to a minimal nitrogen supply. This study assesses the efficiency of a specific breeding program dedicated to improve yield and quality in emmer and spelt wheat in low-input environments. Ten tetraploid (emmer and durum wheat) and four hexaploid (spelt and bread wheat) wheat genotypes (including parent cultivars and offspring breeding lines selected for adaptation to low-input conditions) were investigated for $1 \mathrm{yr}$ (2003-2004) in Italy in three locations in conventional and low-input cropping systems. The main agro-morphological and qualitative traits were recorded (HD, PH, GY, PC GPY, TKW, TW, GC). The results of this study show encouraging agronomic performances of new emmer and spelt genotypes under conventional and low-input cropping systems. The new genotypes are characterized by a yield potential similar to that of the modern wheat cultivar as well as by a protein content higher than old emmer and spelt accessions. The new genetic materials were also characterized by a higher responsiveness to improved environmental conditions. The results described in this study support the suitability of modern emmer and spelt genotypes, improved by introgressing wheat yield and quality traits, for organic farming in Mediterranean environments.
\end{abstract}

Key-words: emmer, spelt, wheat, old cultivars, new cultivars, low-input, yield, protein content.

\section{Introduction}

Wheat production in many areas of Mediterranean basin is particularly dependent on synthetic nitrogen fertilizers because the use of animal manure is very limited, many of the soils are naturally low in levels of soil organic matter and there are few legumes present in the main wheat rotations that could supply symbiotically fixed nitrogen (López-Bellido et al., 2000; Masri and John Ryan, 2006; Rodriquez et al., 2006). Therefore, continuous wheat and wheat-fallow systems in South Europe are facing challenges from environmental and economic perspectives, especially with higher than normal fertilizer nitrogen costs and relatively low wheat prices.

This situation could be made more severe for wheats species by increased interest on low-input/organic farming characterised by reduced use of pesticides and chemical fertilizers in order to realize sustainable crop production which 
can easily integrate in the common agricultural policy. The fast growing market for organic products has created a much more favourable situation for research in the selection and/or plant breeding of crop cultivars which are suitable for sustainable and organic production systems. Therefore, diversified cropping systems are being studied that are profitable, and improve, or maintain soil fertility. It is expected that the main goals for cereal breeding dedicated to low-input and organic farming will be encountered by: i) ability to suppress weeds, longer straw; ii) stability of yield and quality under different conditions (nutrient uptake efficiency, resistance to abiotic stress factors) and iii) high quality and stability of quality characteristics under extensive conditions (van Lammerts Bueren et al., 2002; Mason and Spaner, 2006).

Emmer (Triticum turgidum L. subsp. dicoccum Schrank, $2 \mathrm{n}=4 \mathrm{X}=28$; genomes AABB) and Spelt (Triticum aestivum L. subsp. spelta, $2 \mathrm{n}$ $=6 \mathrm{X}=42$; genomes AABBDD) hulled wheats were the main cereal crops in the Mediterranean basin during the Roman period (Damania et al., 1992; Nesbitt and Samuel 1995), progressively replaced with hulless durum ( $T$. turgidum subsp. durum Desf., genomes AABB) and bread (T. aestivum L. subsp. aestivum L., genomes AABBDD) wheat.

Hulled wheats, often, are grown in marginal hill and mountain areas (up to 1500 meters above sea level) in organic farms, especially in Italy, where they are considered suitable crops for sustainable farming systems (Castagna et al., 1996). Despite a number of defects as plant height, low grain yield and low pasta- and bread-making quality, spelt and emmer have been recovered in modern times thanks to their adaptability to poor soils and unfavourable climatic conditions (Perrino and Hammer, 1984; Pisante et al., 1996).

During the last decade field evaluations of germplasm collections have been carried out to assess variation in agronomic (Damania et al., 1992; Troccoli et al., 1997; Laghetti et al., 1999; Troccoli and Codianni, 2005) and quality traits (Galterio et al., 1994; Cubadda and Marconi 1995; Galletti et al., 1996). Storage protein markers have also been used to assess the level of variability within and between populations and to identify components associated with bread- and pasta-making quality (Ranhotra et al., 1995; Galterio et al., 1998; Galterio et al., 2000; Galterio et al., 2001; Marconi et al., 2002; Piergiovanni and Volpe, 2003; Degaonkar et al., 2005).

Breeding programs aimed to improve yield stability and quality traits lead to several new emmer and spelt cultivars (Fares et al., 2000; Galterio et al., 2001) characterized by the introgression of some durum or bread traits into emmer or spelt genotypes while preserving the morphological, functional and botanical characteristics of emmer and spelt (Galterio et al., 2000; Fares et al., 2001; Galterio et al., 2003; De Vita et al., 2006).

An important question is whether these new genotypes possess the right combinations of characteristics, e.g. stable and acceptable yield and good quality when grown under different growing conditions. Such efforts are also consistent with the 'organic plant breeding' aiming to develop cultivars for organic agriculture (van Lammerts Bueren et al., 2003).

This study aimed to evaluate the agronomic performance of selected advanced breeding lines bred under conventional and low-input/organic growing conditions to identify the suitable genotypes for organic farming in Mediterranean environments.

\section{Materials and methods}

\subsection{Genetic materials}

The genetic materials evaluated in the experiments were the result of a specific breeding program developed at the CRA Centro di ricerca per la cerealicoltura aiming to select emmer and spelt genotypes with superior performances in low-input and organic farming systems (Fares et al., 2000; Galterio et al., 2001). The evaluated genotypes included both progenitors and $\mathrm{F}_{8}$ advanced lines for a total of 14 wheat accessions representing two levels of ploidy as indicated in Table 1.

\subsection{Agronomic management}

The trials have been carried out during the 2003-2004 growing season in three different locations (Foggia, Catania and Rome) representative for the main cereals growing areas in Italy (Tab. 2). Foggia and Catania are characterized 
Table 1. List of genotypes evaluated in conventional and low-input growing systems. The ploidy level and the origin are also reported.

\begin{tabular}{|c|c|c|c|}
\hline $\begin{array}{l}\text { Ploidy levels } \\
\mathrm{x}=7\end{array}$ & Genotypes & Group & Origin \\
\hline \multirow[t]{9}{*}{$4 x$} & $\begin{array}{l}\text { Molise } \\
\text { Umbria }\end{array}$ & Old Emmer populations & $\begin{array}{l}\text { Old Italian population } \\
\text { Old Italian population }\end{array}$ \\
\hline & Mosè & & $\begin{array}{l}\text { Triticum dicoccum Schubler Molise x Triticum durum } \\
\text { Desf. cv. Simeto }\end{array}$ \\
\hline & Davide & Emmer cultivars & $\begin{array}{l}\text { Triticum dicoccum Schubler Molise x Triticum durum } \\
\text { Desf. cv. Simeto }\end{array}$ \\
\hline & Padre Pio & & $\begin{array}{l}\text { Triticum dicoccum Schubler Molise x Triticum durum } \\
\text { Desf. cv. Simeto }\end{array}$ \\
\hline & 172 r R & & $\begin{array}{l}\text { Triticum dicoccum Schubler Molise x Triticum durum } \\
\text { Desf. cv. Ofanto }\end{array}$ \\
\hline & 209 r R & Advanced Emmer lines & $\begin{array}{l}\text { Triticum dicoccum Schubler Molise x Triticum durum } \\
\text { Desf. cv. Ofanto }\end{array}$ \\
\hline & 223 r R & & $\begin{array}{l}\text { Triticum dicoccum Schubler Molise x Triticum durum } \\
\text { Desf. cv. Ofanto }\end{array}$ \\
\hline & Simeto & Durum wheat cultivar & $\begin{array}{l}\text { Triticum durum Desf. cv. Capeiti } 8 \text { x Triticum durum } \\
\text { Desf. cv. Valnova }\end{array}$ \\
\hline & Ofanto & & $\begin{array}{l}\text { Triticum durum Desf. cv. Appulo x Triticum durum } \\
\text { Desf. cv. Valnova }\end{array}$ \\
\hline \multirow[t]{4}{*}{$6 x$} & Altgold Rotkorn & Old Spelt cultivar & Old european spelt cultiver \\
\hline & B1030 & Advanced Spelt lines & $\begin{array}{l}\text { Triticum spelta L. cv. Altgold Rotkorn x Triticum aesti- } \\
\text { vum L. cv. Bolero }\end{array}$ \\
\hline & B1037 & & $\begin{array}{l}\text { Triticum spelta L. cv. Altgold Rotkorn x Triticum aesti- } \\
\text { vum L. cv. Bolero }\end{array}$ \\
\hline & Bolero & Bread wheat cultivar & \\
\hline
\end{tabular}

by Mediterranean climatic conditions, while in Rome the climate is temperate. Two different levels of agronomic inputs were applied in a randomized complete block design with three replications and $10 \mathrm{~m}^{2}$ plots: i) low-input cropping system and ii) conventional cropping system. In the low-input system, $40 \mathrm{Kg} \mathrm{ha}^{-1}$ of ni- trogen $(\mathrm{N})$ organic fertilizer (nitrification inhibitors) were applied in one rate at the sowing date in Foggia accordingly to the standard practices adopted by organic farmers in the region, while at Catania and Rome any fertilizing treatment was performed considering sufficient the nitrogen residue from the previous crop. In the

Table 2. Characteristics of the experimental sites.

\begin{tabular}{|c|c|c|c|}
\hline Location & Foggia & Rome & Catania \\
\hline \multirow[t]{2}{*}{ Coordinates } & $41^{\circ} 28^{\prime} \mathrm{N}$ & $43^{\circ} 07^{\prime} \mathrm{N}$ & $37^{\circ} 31^{\prime} \mathrm{N}$ \\
\hline & $15^{\circ} 32^{\prime} \mathrm{E}$ & $12^{\circ} 21^{\prime} \mathrm{E}$ & $14^{\circ} 34^{\prime} \mathrm{E}$ \\
\hline Altitude (m asl) & 75 & 20 & 180 \\
\hline Soil type & Clay-loam & Clay-loam & Sandy-clay-loam \\
\hline Sand $(\%)$ & 25.7 & 30.1 & 50.3 \\
\hline Loam (\%) & 33.0 & 39.9 & 27.6 \\
\hline Clay $(\%)$ & 41.3 & 30.0 & 22.1 \\
\hline Field capacity $\left(\mathrm{cm}^{3}\right.$ water $/ \mathrm{cm}^{3}$ soil $)$ & 0.37 & 0.31 & 0.25 \\
\hline Wilting point $\left(\mathrm{cm}^{3}\right.$ water $/ \mathrm{cm}^{3}$ soil $)$ & 0.23 & 0.17 & 0.14 \\
\hline Available water $\left(\mathrm{cm}^{3}\right.$ water $/ \mathrm{cm}^{3}$ soil $)$ & 0.14 & 0.15 & 0.11 \\
\hline $\mathrm{pH}\left(\mathrm{CaCl}_{2}\right)$ & 7.8 & 7.0 & 7.6 \\
\hline Total N (g/kg) & 1.4 & 1.3 & 1.0 \\
\hline Organic matter (\%) & 2.2 & 2.1 & 2.2 \\
\hline $\mathrm{P}$ assimilable $(\mathrm{mg} / \mathrm{kg})$ & 12.0 & 18.9 & 27.5 \\
\hline
\end{tabular}


Table 3. Management details of low-input and conventional cropping systems at Foggia, Catania and Rome.

\begin{tabular}{|c|c|c|c|c|c|c|c|c|}
\hline \multirow{2}{*}{$\begin{array}{l}\text { Cropping } \\
\text { system }\end{array}$} & \multirow[t]{2}{*}{ Location } & \multirow{2}{*}{$\begin{array}{l}\text { Sowing } \\
\text { date }\end{array}$} & \multirow{2}{*}{$\begin{array}{l}\text { Previous } \\
\text { crop }\end{array}$} & \multicolumn{3}{|c|}{ Fertilizer $\left(\mathrm{kg} \mathrm{ha}^{-1}\right)$} & \multirow[t]{2}{*}{ Weed control } & \multirow[t]{2}{*}{ Harvest date } \\
\hline & & & & $\begin{array}{l}\text { pre- } \\
\text { sowing } \\
\mathrm{N}\end{array}$ & $\mathrm{P}_{2} \mathrm{O}_{5}$ & $\begin{array}{c}\text { top- } \\
\text { dressing } \\
\mathrm{N}\end{array}$ & & \\
\hline \multirow[t]{3}{*}{ Conventional } & Foggia & $21-12-03$ & Fallow & 36 & 92 & 52 & $\begin{array}{l}\text { Herbicide: Clodinafop- } \\
\text { propargile + cloropiralid } \\
\text { + fluroxipir + MCPA }\end{array}$ & $22-06-04$ \\
\hline & Rome & $20-11-03$ & Corn & 36 & 92 & 100 & Manually & 08-07-04 \\
\hline & Catania & $3-12-03$ & Fallow & 36 & 92 & - & $\begin{array}{l}\text { Diclofop-metyl + } \\
\text { tribenuron-methyl }\end{array}$ & $28-6-04$ \\
\hline \multirow[t]{3}{*}{ Low-input } & Foggia & $20-12-03$ & Chick-pea & 40 & - & - & Manually & 24-06-04 \\
\hline & Rome & $20-11-03$ & Alfalfa & - & - & - & Manually & 09-07-04 \\
\hline & Catania & $13-1-04$ & Vetch & - & - & - & Manually & $7-7-04$ \\
\hline
\end{tabular}

conventional cropping system $90 \mathrm{Kg} \mathrm{ha}^{-1}$ of $\mathrm{N}$ fertilizer were applied at Foggia and Catania in two rates: $1 / 3$ at sowing and $2 / 3$ at tillering stage, while at Rome $136 \mathrm{Kg} \mathrm{ha}^{-1}$ of $\mathrm{N}$ fertilizer were applied with the same splitting time. The field trials were sown in moist conditions and no irrigation was applied thereafter. Seedling density was 200 seeds $\mathrm{m}^{-2}$ (Troccoli and Codianni, 2005). In table 3 the agronomic practices adopted in the field trials are reported. Daily maximum and minimum temperatures and rainfall were recorded at the meteorological station beside the experimental fields (Fig. 1).

\subsection{Observed traits}

The genetic materials were characterized for morphological and qualitative traits. The following traits were observed:

1. Heading date (HD, days after $1^{\text {th }}$ April): it was recorded when about half of the culms showed emerging spikes (growth stage 55, Zadoks et al., 1974).

2. Plant height $(\mathrm{PH}, \mathrm{cm})$ : it was measured in all plots, during the milk-waxy ripening, corresponding to maximum plant height.

3. Grain yield $\left(\mathrm{GY}, \mathrm{t} \mathrm{ha}^{-1}\right)$ : the weight of hulled grain mechanically harvested from a plot trial.

4. Grain protein yield (GPY, $\mathrm{tha}^{-1}$ ): determined as grain protein content $\mathrm{x}$ grain yield/100.

5. Thousand kernel weight (TKW, g): it was calculated as the mean weight of three sets of 100 grains per plot.

6. Test weight (TW, $\mathrm{kg} \mathrm{hl}^{-1}$ ): defined as the weight of a given volume of seeds was measured on a $250 \mathrm{~g}$ sample by means of a Shopper chondrometer equipped with a $1 / 4$ litre container. Each measure was made in duplicate.

7. Grain protein content (PC, \% N x 5.70): it was determined on duplicate samples according to UNI 10274 and expressed on dry weight basis.

8. Dry gluten (GC) was determined in triplicate on flour and semolina according to approved methods UNI 10689. For the determination of dry gluten, wet gluten was dried with Glutorx 2020 at $150{ }^{\circ} \mathrm{C}$ for 5 minutes and left to cool for 3 minutes.

\subsection{Statistical analysis}

Statistical analysis was conducted for each parameter by analysis of variance (ANOVA) in a factorial design separately for hexaploid and tetraploid wheat species. Least significant difference (LSD) values were calculated at the 5\% probability level using Mstat-C version 2.00 software (Michigan State University, MI, USA). The slope of the genotype regression on environment mean yield and protein content (Finlay and Wilkinson, 1963) were calculated.

\section{Results}

\subsection{Weather}

As expected, rainfall was concentrated from the end of autumn to the beginning of spring (Fig. 1). The 2003-2004 growing season was characterized in all three locations by a mild winter and a rainfall of about 475, 500 and $880 \mathrm{~mm}$ at Catania, Foggia and Rome respectively (values all above the long-term average data). Precipitations were very abundant from October to June at Rome and at Catania allowing flower- 

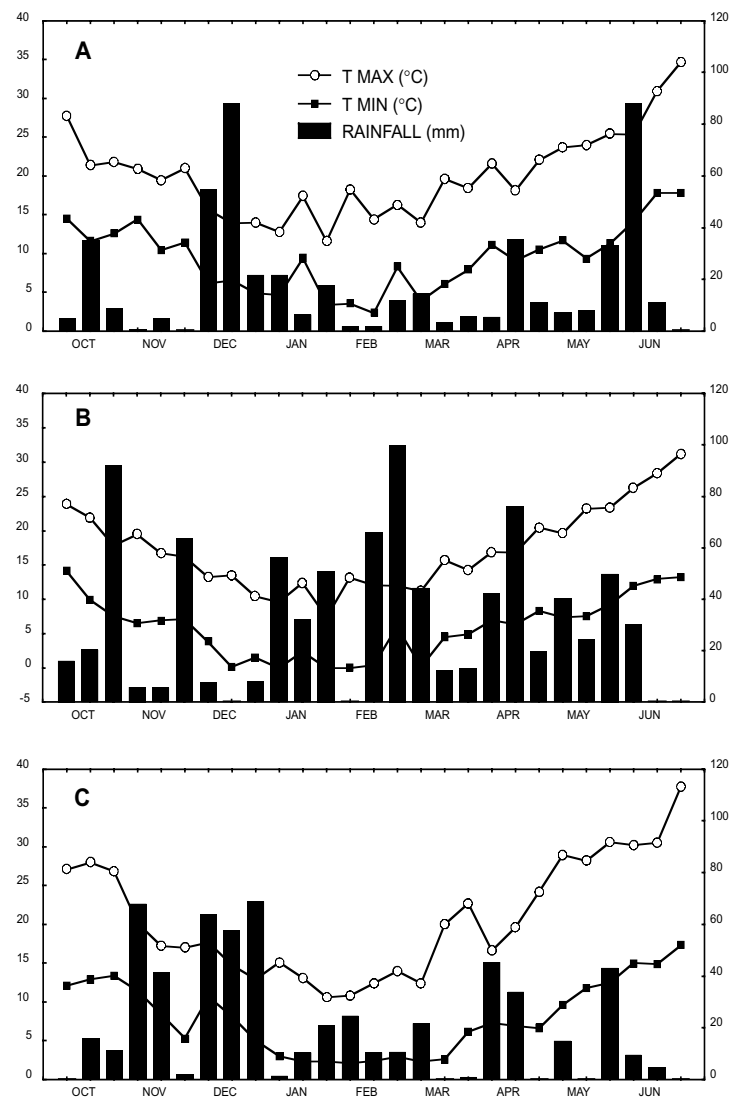

Figure 1. Trend of temperature and rainfall at Foggia (A), Roma (B) and Catania (C) during the growing season.

ing and maturity to proceed without water stress. At Foggia the rain was less abundant during stem elongation.

\subsection{General effects of genotype, cropping system} and location

Tables 4 and 5 summarized the mean square of each factor and their interactions for all traits evaluated in the study. Considering the main factor all traits showed statistically significant variations with the exception of $\mathrm{HD}, \mathrm{PH}$ and TKW for the cropping system factor. Almost all the first order interactions were statistically significant with the exception of HD and TW for the hexaploid accessions and $\mathrm{PH}$ for the tetraploid ones. Finally, among the cropping system (CS) $x$ location (L) $x$ genotype $(\mathrm{G})$ only the $\mathrm{HD}$ and the $\mathrm{PH}$ traits showed a lack of significance. Although it is true that the interactions were mostly statistically significant, it is also true that they were of relatively little biological importance. For instance, regarding yield as the main attribute (but this is true for most of the attributes considered) the mean square (MS) of G was far greater than the MS of the interactions. This might be interpreted as a primary evidence that the interaction, although statistically significant, might not represent major changes in cultivar rankings for most attributes. Since the key objective of this study was to assess the performances of selected breeding lines respect to their parents, we analyzed in details the main effects of $G$ (breeding effects) on the average of all 6 environments ( 2 agronomic treatments $\times 3$ locations), as the general trend would be rather similar, then some considerations on the interactions will be added.

Table 4. Analysis of variance (mean square and significance) of agronomical and qualitative traits of hexaploid accessions evaluated.

\begin{tabular}{|c|c|c|c|c|c|c|c|c|c|}
\hline Source & $\mathrm{DF}$ & GY & HD & $\mathrm{PH}$ & GPY & TW & TKW & $\mathrm{PC}$ & $\mathrm{GC}$ \\
\hline Rep & 2 & $0.1 \mathrm{~ns}$ & $4.7 \mathrm{~ns}$ & $45.4 \mathrm{~ns}$ & $0.0 *$ & $2.6 \mathrm{~ns}$ & $9.6 \mathrm{~ns}$ & $0.9 \mathrm{~ns}$ & $3.1 \mathrm{~ns}$ \\
\hline Cropping systems (CS) & 1 & $18.4 * * *$ & 19.0ns & $144.5 \mathrm{~ns}$ & $1.1 * * *$ & $44.2 *$ & $2.8 \mathrm{~ns}$ & $132.2 * * *$ & $99.4 *$ \\
\hline Error & 2 & 0.0 & 2.5 & 273.0 & 0.0 & 3.8 & 4.4 & 0.1 & 2.4 \\
\hline Location (L) & 2 & $13.2 * * *$ & $2718.8 * * *$ & $7359.0 * * *$ & $0.1 * * *$ & $33.3 * * *$ & $628.4 * * *$ & $13.9 * * *$ & $48.4 * * *$ \\
\hline $\mathrm{CS} \times \mathrm{L}$ & 2 & $14.6 * * *$ & $17.7 * * *$ & $341.1 * * *$ & $0.5 * * *$ & $48.8 * * *$ & $99.3 * * *$ & $32.7 * * *$ & $30.4 * * *$ \\
\hline Genotype (G) & 3 & $36.2 * * *$ & $5328.9 * * *$ & $16757.2 * * *$ & $1.3 * * *$ & $534.0 * * *$ & $420.7 * * *$ & $64.2 * * *$ & $43.1 * * *$ \\
\hline $\mathrm{CS} \times \mathrm{G}$ & 3 & $6.1 * * *$ & $7.8 \mathrm{~ns}$ & $319.0 * * *$ & $0.2 * * *$ & $11.0^{*}$ & $71.3 * * *$ & $13.1 * * *$ & $7.1^{*}$ \\
\hline $\mathrm{L} \times \mathrm{G}$ & 6 & $2.6 * * *$ & $54.8 * * *$ & $1591.1 * * *$ & $0.0 * * *$ & $16.5 \mathrm{~ns}$ & $132.6^{* * *}$ & $7.0 *$ & $12.8^{*}$ \\
\hline $\mathrm{CS} \times \mathrm{L} \times \mathrm{G}$ & 6 & $1.9 * * *$ & $12.0 \mathrm{~ns}$ & $306.8 * *$ & $0.0 * * *$ & $19.5 *$ & $54.1 * * *$ & $11.6 * *$ & $11.2 *$ \\
\hline Residual & 44 & 1.5 & 42.1 & 670.2 & 0.1 & 55.0 & 56.8 & 20.0 & 20.6 \\
\hline Total & 71 & 94.7 & 8208.3 & 2787.3 & 3.5 & 768.6 & 1479.9 & 295.6 & 278.8 \\
\hline $\mathrm{CV} \%$ & & 4.9 & 2.9 & 3.7 & 6.8 & 1.5 & 2.9 & 4.8 & 6.6 \\
\hline
\end{tabular}

$\mathrm{GY}=$ grain yield $\left(\mathrm{t} \mathrm{ha}^{-1}\right) ; \mathrm{HD}=$ hading date, starting from $1^{\text {th }}$ April; $\mathrm{PH}=$ plant height $(\mathrm{cm}) ; \mathrm{TW}=$ test weight $\left(\mathrm{kg} \mathrm{hl}^{-1}\right)$; TKW $=$ thousand kernel weight $(\mathrm{g})$; PC = protein content $(\%)$; GPY = grain protein yield $\left(\mathrm{t} \mathrm{ha}^{-1}\right)$; GC = gluten content $(\mathrm{g})$; ns: not significant; level of statistical significance: $* \mathrm{P}<0.1 ; * * \mathrm{P}<0.01$; *** $\mathrm{P}<0.001$. 
Table 5. Analysis of variance (mean square and significance) of agronomical and qualitative traits of tetraploid accessions evaluated.

\begin{tabular}{|c|c|c|c|c|c|c|c|c|c|}
\hline Source & DF & GY & HD & $\mathrm{PH}$ & GPY & TW & TKW & $\mathrm{PC}$ & $\mathrm{GC}$ \\
\hline Rep & 2 & $0.2 \mathrm{~ns}$ & $0.8 \mathrm{~ns}$ & $68.8 \mathrm{~ns}$ & $0.0 \mathrm{~ns}$ & $0.8 \mathrm{~ns}$ & 7.6ns & $2.2 \mathrm{~ns}$ & $3.3^{*}$ \\
\hline Cropping systems (CS) & 1 & $39.9 * * *$ & $1.4 \mathrm{~ns}$ & $402.0 \mathrm{~ns}$ & $1.5 * * *$ & $35.3 * *$ & $42.2 \mathrm{~ns}$ & $107.3 * *$ & $63.1 * * *$ \\
\hline Error & 2 & 0.0 & 0.3 & 136.8 & 0.0 & 0.2 & 6.4 & 0.2 & 0.0 \\
\hline Location (L) & 2 & $9.8 * * *$ & $9010.6^{* * *}$ & $3333.6 * * *$ & $0.1 * * *$ & $198.8 * * *$ & $1276.9 * * *$ & $91.5 * * *$ & $191.9 * * *$ \\
\hline $\mathrm{CS} \times \mathrm{L}$ & 2 & $26.0 * * *$ & $8.6^{* * *}$ & $820.2 * * *$ & $0.7 * * *$ & $100.3 * * *$ & $149.5 * * *$ & $25.0 * * *$ & $21.5 * * *$ \\
\hline Genotype (G) & 9 & $63.8 * * *$ & $6623.7 * * *$ & $63725.8^{* * *}$ & $1.8 * * *$ & $851.7 * * *$ & $5249.8 * * *$ & $185.3^{* * *}$ & $220.6^{* * *}$ \\
\hline $\mathrm{CS} \times \mathrm{G}$ & 9 & $8.6^{* * * *}$ & $18.3 *$ & $996.8 * * *$ & $0.2 * * *$ & $47.8 * * *$ & $100.6^{* * * *}$ & $12.1 * * *$ & $6.9^{*}$ \\
\hline$L \times G$ & 18 & $10.8 * * *$ & $147.0 * * *$ & $678.8 \mathrm{~ns}$ & $0.2 * * *$ & $99.8 * *$ & $731.2 * * *$ & $24.8 * * *$ & $33.0 * * *$ \\
\hline $\mathrm{CS} \times \mathrm{L} \times \mathrm{G}$ & 18 & $7.6 * * *$ & $21.3 \mathrm{~ns}$ & $378.4 \mathrm{~ns}$ & $0.2 * * *$ & $65.1 * *$ & $150.2 * * *$ & $13.7 * *$ & $12.6^{*}$ \\
\hline Residual & 116 & 3.9 & 94.8 & 2696.3 & 0.1 & 186.1 & 273.3 & 41.0 & 45.3 \\
\hline Total & 179 & 170.6 & 15927.0 & 73237.7 & 5.0 & 1586.0 & 7987.9 & 503.4 & 598.4 \\
\hline $\mathrm{CV} \%$ & & 5.5 & 3.5 & 4.6 & 7.1 & 1.7 & 3.4 & 4.3 & 6.0 \\
\hline
\end{tabular}

$\mathrm{GY}=$ grain yield $\left(\mathrm{t} \mathrm{ha}^{-1}\right) ; \mathrm{HD}=$ hading date, starting from $1^{\text {th }}$ April; $\mathrm{PH}=$ plant height $(\mathrm{cm}) ; \mathrm{TW}=$ test weight $\left(\mathrm{kg} \mathrm{hl}^{-1}\right) ; \mathrm{TKW}^{-}$ thousand kernel weight $(\mathrm{g}) ; \mathrm{PC}=$ protein content $(\%)$; GPY $=$ grain protein yield $\left(\mathrm{t} \mathrm{ha}^{-1}\right) ; \mathrm{GC}=$ gluten content $(\mathrm{g})$; ns: not significant; level of statistical significance: $* \mathrm{P}<0.1$; $* * \mathrm{P}<0.01$; *** $\mathrm{P}<0.001$.

\subsection{Genotype effects within tetraploid and hexa- ploid wheats}

Considering the tetraploid genotypes, yield was lower in the old emmer genotypes (2.32 and $2.54 \mathrm{t} \mathrm{ha}^{-1}$ for Umbria and Molise respectively) whereas modern cultivars (Ofanto and Simeto durum wheat) and advanced breeding lines were more productive. In particular, Davide $\left(4.07 \mathrm{t} \mathrm{ha}^{-1}\right)$, Mosè $\left(3.95 \mathrm{t} \mathrm{ha}^{-1}\right)$ and Simeto $(3.87$ $\mathrm{t}$ ha-1) showed the best yield considering the mean performance in both low- and high-input trials.

Similar differences were registered for HD among the evaluated genotypes (Tab. 6). The results showed a significant reduction of the vegetative period for all selected breeding lines compared to the old progenitors (22.5 vs. 37.2 days from $1^{\text {th }}$ April, respectively). The selective pressure was less evident for $\mathrm{PH}$, although the mean values for this trait showed a certain reduction and variability among the emmer breeding lines.

The effects of the selection was also evident for TW, TKW, PC, GPY and GC (Tab. 6). For all these traits, the mean values of the advanced breeding lines were quite similar to the values recorded for durum cultivars and higher than the corresponding values recorded for the old populations. Particularly evident was the difference between the PC of advanced emmer lines and parental cultivars $(14.5 \%$ vs. $12.8 \%$ and $12.9 \%$ for advanced emmer lines, durum culti- vars and old populations, respectively). Overall, the new hulled wheat genotypes were best performing for yield, protein and gluten contents and the emmer cultivar Davide could be considered the most interesting tetraploid for all tested parameters.

Regarding the hexaploid accessions, the grain yield of the tested genotypes ranged from $2.59 \mathrm{t} \mathrm{ha}^{-1}$ (Altgold Rotkorn) to $4.36 \mathrm{t} \mathrm{ha}^{-1}$ (advanced spelt line B1030) (Tab. 7). Mean grain yield values were higher for the modern bread cultivars and advanced spelt lines than in the old cultivar. Similar differences were registered for all the agro-morphological traits evaluated (Tab. 7). The HD for the advanced spelt lines was middle (31.7 days from $1^{\text {th }}$ April) compared to the two parents (from 47.8 to 24.3 days from $1^{\text {th }}$ April for old spelt and bread cultivar, respectively). Regarding the $\mathrm{PH}$ the differences between the old progenitor (Altgold Rotkorn) and the advanced spelt lines, although statistically significant, did not show substantial reduction in $\mathrm{PH}$.

The mean values of the advanced spelt lines for quality-related traits were quite similar to the values of the bread cultivar Bolero and higher than the corresponding values of Altgold Rotkorn. Particularly evident was the difference between the PC of the two advanced spelt lines and the same trait of the parents $(14.9 \%$ vs. $13.7 \%$ and $12.8 \%$ for advanced spelt lines, Bolero and Altgold Rotkorn, respectively). 
Table 6. Mean values of recorded parameters for all tetraploid accessions. The mean values are also reported for locations and cropping systems.

\begin{tabular}{|c|c|c|c|c|c|c|c|c|}
\hline Genotype & GY & HD & $\mathrm{PH}$ & TW & TKW & PC & GPY & GC \\
\hline Molise & 2.54 & 37.7 & 124.8 & 71.6 & 43.8 & 13.0 & 0.330 & 10.2 \\
\hline Umbria & 2.32 & 36.8 & 112.4 & 71.7 & 31.7 & 12.8 & 0.294 & 9.6 \\
\hline Old emmer populations & 2.43 & 37.2 & 118.6 & 71.7 & 37.7 & 12.9 & 0.312 & 9.9 \\
\hline Mosè & 3.95 & 21.9 & 83.6 & 75.1 & 48.8 & 14.4 & 0.572 & 10.8 \\
\hline Davide & 4.07 & 20.8 & 111.8 & 75.1 & 52.8 & 15.8 & 0.644 & 12.2 \\
\hline Padre Pio & 3.74 & 21.6 & 117.4 & 78.2 & 45.8 & 14.5 & 0.548 & 10.9 \\
\hline $172 \mathrm{R}$ & 3.11 & 25.9 & 118.2 & 76.4 & 49.7 & 14.0 & 0.440 & 10.8 \\
\hline $209 \mathrm{R}$ & 2.82 & 21.2 & 126.1 & 73.7 & 45.5 & 15.0 & 0.435 & 11.8 \\
\hline $223 \mathrm{R}$ & 3.66 & 23.7 & 85.7 & 73.2 & 47.8 & 13.4 & 0.490 & 9.9 \\
\hline Advanced emmer lines & 3.56 & 22.5 & 107.1 & 75.3 & 48.4 & 14.5 & 0.521 & 11.1 \\
\hline Simeto & 3.87 & 21.4 & 78.1 & 77.8 & 44.8 & 13.1 & 0.508 & 8.8 \\
\hline Ofanto & 3.64 & 24.0 & 77.8 & 75.4 & 42.3 & 12.5 & 0.462 & 8.7 \\
\hline Durum wheat cultivars & 3.76 & 22.7 & 77.9 & 76.6 & 43.5 & 12.8 & 0.485 & 8.7 \\
\hline $\mathrm{LSD}_{0.05}$ & 0.12 & 0.6 & 3.2 & 0.8 & 1.0 & 0.4 & 0.021 & 0.4 \\
\hline \multicolumn{9}{|l|}{ Cropping system } \\
\hline Low-input & 2.90 & 25.6 & 105.1 & 75.3 & 45.7 & 13.1 & 0.380 & 9.8 \\
\hline Conventional & 3.84 & 25.4 & 102.1 & 74.4 & 44.8 & 14.6 & 0.565 & 11.0 \\
\hline $\mathrm{LSD}_{0.05}$ & 0.10 & 0.3 & 5.2 & 0.2 & 1.1 & 0.2 & 0.020 & 0.1 \\
\hline \multicolumn{9}{|l|}{ Location } \\
\hline Foggia & 3.50 & 31.2 & 99.5 & 76.3 & 42.4 & 14.3 & 0.504 & 11.6 \\
\hline Roma & 3.57 & 29.7 & 109.5 & 73.9 & 48.8 & 12.8 & 0.460 & 9.0 \\
\hline Catania & 3.04 & 15.5 & 101.7 & 74.2 & 44.6 & 14.4 & 0.453 & 10.5 \\
\hline $\mathrm{LSD}_{0.05}$ & 0.07 & 0.3 & 1.7 & 0.4 & 0.5 & 0.2 & 0.01 & 0.2 \\
\hline
\end{tabular}

$\mathrm{GY}=$ grain yield $\left(\mathrm{t} \mathrm{ha}^{-1}\right) ; \mathrm{HD}=$ hading date, starting from $1^{\text {th }}$ April; $\mathrm{PH}=$ plant height $(\mathrm{cm}) ; \mathrm{TW}=$ test weight $\left(\mathrm{kg} \mathrm{hl}^{-1}\right)$; TKW $=$ thousand kernel weight $(\mathrm{g}) ; \mathrm{PC}=$ protein content $(\%)$; GPY = grain protein yield $\left(\mathrm{t} \mathrm{ha}{ }^{-1}\right) ; \mathrm{GC}=$ gluten content $(\mathrm{g}) ; \mathrm{LSD}=\mathrm{least}$ significant difference.

Table 7. Mean values of recorded parameters for all hexaploid accessions. The mean values are also reported for locations and cropping systems.

\begin{tabular}{|c|c|c|c|c|c|c|c|c|}
\hline Genotype & GY & HD & $\mathrm{PH}$ & TW & TKW & $\mathrm{PC}$ & GPY & $\mathrm{GC}$ \\
\hline Altgold Rotkorn & 2.59 & 47.8 & 117.4 & 72.1 & 38.8 & 12.8 & 0.330 & 9.5 \\
\hline Old spelt cultivar & 2.59 & 47.8 & 117.4 & 72.1 & 38.8 & 12.8 & 0.330 & 9.5 \\
\hline B 1030 & 4.36 & 31.6 & 107.4 & 77.3 & 42.3 & 15.4 & 0.688 & 11.6 \\
\hline B 1037 & 4.01 & 31.9 & 113.8 & 77.6 & 37.4 & 14.4 & 0.591 & 10.7 \\
\hline Advanced spelt lines & 4.18 & 31.7 & 110.6 & 77.4 & 39.8 & 14.9 & 0.639 & 11.1 \\
\hline Bolero & 4.23 & 24.3 & 78.6 & 79.4 & 35.8 & 13.7 & 0.584 & 10.0 \\
\hline Bread wheat cultivar & 4.23 & 24.3 & 78.6 & 79.4 & 35.8 & 13.7 & 0.584 & 10.0 \\
\hline $\mathrm{LSD}_{0.05}$ & 0.12 & 0.7 & 2.6 & 0.7 & 0.8 & 0.4 & 0.021 & 0.5 \\
\hline \multicolumn{9}{|l|}{ Cropping system } \\
\hline Low-input & 3.29 & 33.4 & 102.9 & 77.4 & 38.7 & 12.7 & 0.423 & 9.2 \\
\hline Conventional & 4.30 & 34.4 & 105.7 & 75.8 & 38.4 & 15.4 & 0.673 & 11.6 \\
\hline $\mathrm{LSD}_{0.05}$ & 0.08 & 1.1 & 11.7 & 1.4 & 1.5 & 0.2 & 0.011 & 1.1 \\
\hline \multicolumn{9}{|l|}{ Location } \\
\hline Foggia & 3.92 & 40.3 & 96.0 & 77.2 & 34.8 & 14.3 & 0.567 & 11.4 \\
\hline Roma & 4.24 & 35.7 & 118.5 & 75.7 & 42.0 & 13.5 & 0.578 & 9.4 \\
\hline Catania & 3.22 & 25.6 & 98.3 & 76.8 & 38.9 & 14.4 & 0.499 & 10.4 \\
\hline $\mathrm{LSD}_{0.05}$ & 0.11 & 0.6 & 2.3 & 0.6 & 0.7 & 0.4 & 0.018 & 0.4 \\
\hline
\end{tabular}

$\mathrm{GY}=$ grain yield $\left(\mathrm{t} \mathrm{ha}^{-1}\right) ; \mathrm{HD}=$ hading date, starting from $1^{\text {th }}$ April; $\mathrm{PH}=$ plant height $(\mathrm{cm}) ; \mathrm{TW}=$ test weight $\left(\mathrm{kg} \mathrm{hl}^{-1}\right) ; \mathrm{TKW}^{2}$ thousand kernel weight $(\mathrm{g}) ; \mathrm{PC}=$ protein content $(\%) ; \mathrm{GPY}=$ grain protein yield $\left(\mathrm{t} \mathrm{ha} \mathrm{h}^{-1}\right) ; \mathrm{GC}=$ gluten content $(\mathrm{g})$; LSD $=$ least significant difference. 


\subsection{Cropping system effects}

Thanks to favourable climatic conditions, the GY values were high in both conventional and low-input trials, nevertheless the conventional cropping system yielded significantly more than the low-input cropping system $\left(3.84 \mathrm{t} \mathrm{ha}^{-1} \mathrm{vs}\right.$. $2.90 \mathrm{t} \mathrm{ha}^{-1}$ and $4.30 \mathrm{t} \mathrm{ha}^{-1}$ vs. $3.29 \mathrm{t} \mathrm{ha}^{-1}$ for tetraploid and hexaploid, respectively Tab. 6 and 7). Furthermore, the experimental data also showed that the use of conventional growing techniques positively affected PC, GC and GPY for both tetraploid and hexaploid accessions (Tab. 6 and 7).

\subsection{Location $x$ cropping system interaction effects}

The mean values of the $\mathrm{L} \times \mathrm{CS}$ interaction are shown in table 4 and 5. GY mean values in lowinput conditions were lower than in conventional cropping system in all locations (Tab. 8). A big gap was evident in the trials of Catania where the difference between low-input and conventional cropping system was twofold (2.06 vs. $\left.4.12 \mathrm{t} \mathrm{ha}^{-1}\right)$, a result also due to a delayed sowing of the low-input trial (Tab. 3).

The PC mean values reported in table 8 show that the fertilization applied at sowing in Foggia (40 $\mathrm{N} \mathrm{kg} \mathrm{ha}^{-1}$ ) had significantly affected the grain protein content compared to Rome and Catania where in the low-input trials any nitrogen fertilizer was applied (13.4\% of Foggia vs. 12.6 and $12.9 \%$ of Rome and Catania, respectively), the previous crop was a leguminous for all three locations. In conventional cropping system the PC was higher than in low-input one in all locations. This was greater in Catania and
Foggia (15.9 and $15.2 \%$ compared to 12.9 and $13.4 \%$ for Catania and Foggia, respectively) as indirect consequence of the high temperatures occurred during the grain filling stage which is known to have a concentration effect on kernels (Spiertz, 1977). A similar trend was observed for GC and GPY, while the lowest values for PC and GC were recorded at Rome in both cropping systems.

\subsection{CS $x L \times G$ interaction}

By comparing the accessions over 6 environments ( 2 agronomic treatments $\mathrm{x} 3$ locations) a three-ways interaction for grain yield and protein content was detected (Tab. 2). To assess the ability of the different genotypes to exploit the soil fertility, the accessions were grouped into three classes corresponding to the three main groups indicated in Table 1. The relationship between the average grain yield of each class of genotypes and the trials mean grain yield (environmental index) is shown, for each environment, in Figure 2. Durum and bread cultivars and advanced emmer and spelt lines outyielded old spelt cultivar and old emmer populations in all conditions, furthermore, the wheat cultivars and the advanced spelt and emmer lines also showed a higher slope after linear regression analysis, indicating that they were better responsive to increased environmental fertility (Fig. 2). For instance, the slopes corresponding to the old group of emmer and spelt accessions were 0.52 and 0.63 respectively, while that of the advanced lines were 1.05 and 0.99 for emmer and spelt, respectively, these values were similar to those of the modern parents. The new ge-

Table 8. Mean values of recorded parameters for the three locations in both conventional and low-input growing systems.

\begin{tabular}{lllrrrrrrr}
\hline $\begin{array}{l}\text { Cropping } \\
\text { system }\end{array}$ & Location & GY & HD & PH & TW & TKW & PC & GPY & GC \\
\hline Foggia & 3.52 & 33.4 & 101.7 & 76.4 & 41.5 & 13.4 & 0.472 & 10.7 & \\
Low-input & Roma & 3.45 & 31.7 & 113.0 & 74.5 & 46.8 & 12.6 & 0.438 & 9.0 \\
& Catania & 2.06 & 18.3 & 98.7 & 76.6 & 42.9 & 12.9 & 0.267 & 9.2 \\
& Foggia & 3.72 & 34.3 & 95.3 & 76.7 & 38.9 & 15.2 & 0.572 & 12.4 \\
Conventional & Roma & 4.07 & 31.2 & 111.2 & 74.3 & 46.9 & 13.4 & 0.549 & 9.4 \\
& Catania & 4.12 & 18.5 & 102.9 & 73.4 & 43.1 & 15.9 & 0.666 & 11.6 \\
LSD $_{0.05}$ & & 0.09 & 0.4 & 2.3 & 0.6 & 0.7 & 0.3 & 0.02 & 0.3 \\
\hline
\end{tabular}

$\mathrm{GY}=$ grain yield $\left(\mathrm{t} \mathrm{ha}^{-1}\right) ; \mathrm{HD}=$ hading date, starting from $1^{\text {th }}$ April; $\mathrm{PH}=$ plant height $(\mathrm{cm}) ; \mathrm{TW}=$ test weight $\left(\mathrm{kg} \mathrm{hl}^{-1}\right) ; \mathrm{TKW}=$ thousand kernel weight $(\mathrm{g}) ; \mathrm{PC}=$ protein content $(\%) ; \mathrm{GPY}=$ grain protein yield $\left(\mathrm{t} \mathrm{ha}^{-1}\right) ; \mathrm{GC}=$ gluten content $(\mathrm{g})$; LSD $=$ least significant difference. 

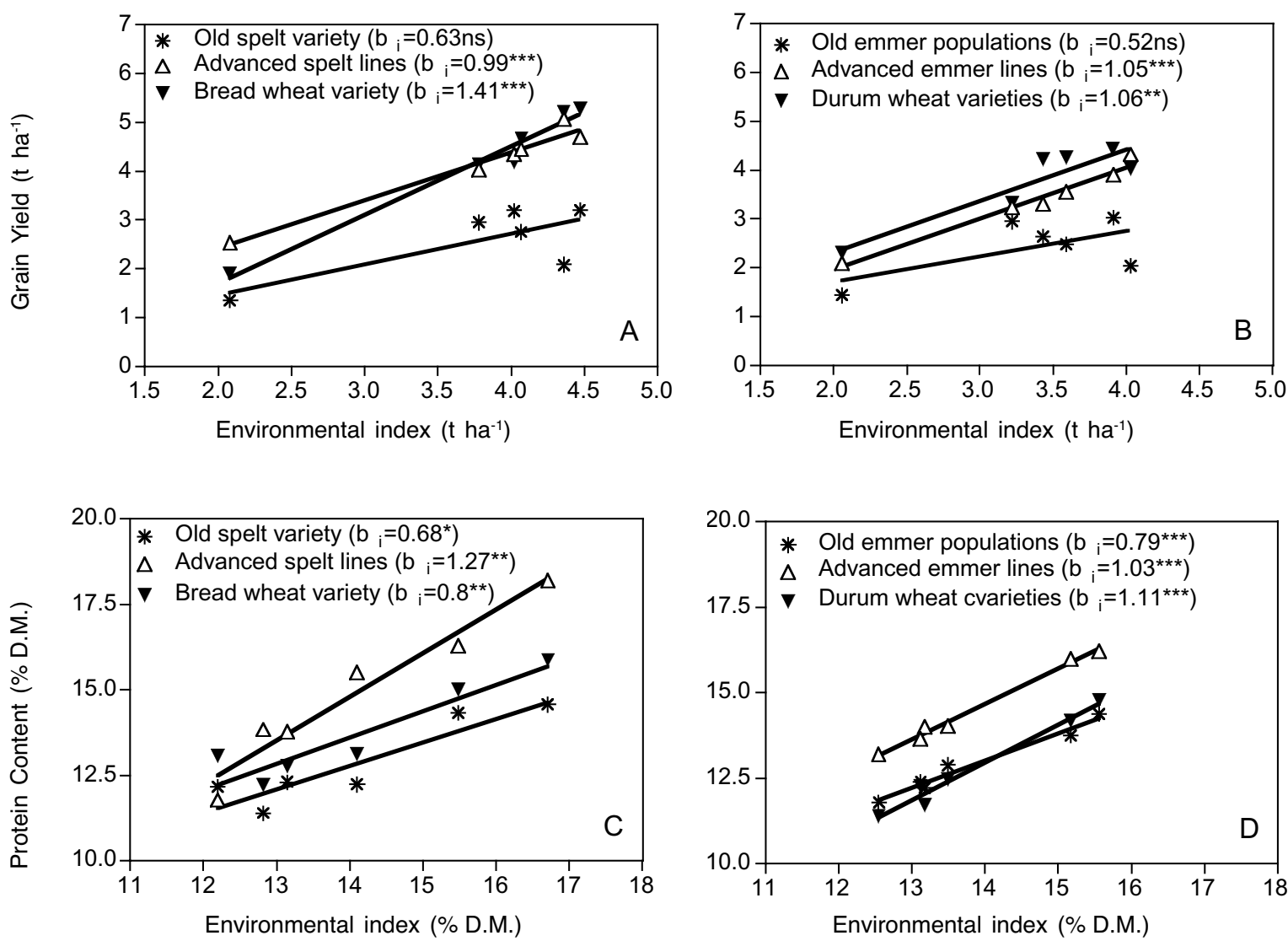

Figure 2. Relationship between grain yield (GY) and protein content (PC) of tetraploid (B and D) and hexaploid (A and C) accessions and the environmental index (mean yield and protein content of all cultivars in each environment, respectively). Lines were fitted by linear regression, assorting the cultivars in three classes corresponding to the Table 1 .

netic materials are therefore characterized by a higher responsiveness to improved environmental conditions. Regarding the grain protein content the performances were even more profitable for the advanced lines (Fig. 2). In fact the new genetic materials showed better values for protein content than both parents in each of the 6 environments.

\section{Discussion}

A central problem with low-input/organic farming is the low nitrogen supply because nitrogen is one of the most important yield limiting factor and an essential component for grain protein (Bloom, 1997; Nass et al., 2003; L-Baeckstrom et al., 2004). Characteristics such as the capacity to assimilate and relocate nitrogen with high efficiency and tolerance to low-input conditions became determinant for the choice of ce- real species and cultivars for sustainable agriculture (Köpke, 2005; Hoad et al., 2005).

Several investigations suggested a superior grain protein content in emmer and spelt than in the corresponding hulless species (durum and bread wheat) (Winzeler and Rüegger, 1990; Galterio et al., 1994; Cubadda and Marconi, 1995) even if this trait is often associated with poor gluten quality (Galterio et al., 1998; Wieser, 2000; Marconi et al., 2002). In addition, spelt and emmer possess a unique flavour, a higher vitamin content and are more nutritious than wheat (Campbell, 1997).

The emmer and spelt cultivars/advanced breeding lines tested in this work have been obtained by crossing emmer and spelt old genotypes (cultivars or populations) with modern cultivars of durum or bread wheat with the aim to improve the yield potential and the quality values of the hulled wheat. During the selection 
process attention was given to the preservation of key morphological and functional traits of emmer and spelt species such as the tough glumes that tightly enclose the grains giving good protection to the stored grains against pests (Nesbitt and Samuel, 1995) and the good adaptability to poor environments. GY was the main selection criterion and the best selected lines were characterized by a yield potential equal to that of the modern durum and bread wheat. In this study a significant genotype by location interaction was observed for GY, nevertheless this results did not lead to a change in genotype/group ranking. Therefore, the analysis was safely based on the across locations average performance. Modern cultivars/advanced lines yielded more than landraces or old cultivars of about 1-1.5 t ha-1 (Tab. 6 and 7).

The data reported in figure 2 indicated that the old genotypes have a high yield stability, but at a very low level in both low-input and conventional cropping systems. Yield stability includes both biological and agronomical components (Becker, 1981; Becker and Leon, 1988). The biological component refers to those genetic traits that confer minimum total variance across different environments. In contrast, a genotype is conventionally considered agronomically stable if it positively responds to high agronomic inputs that may enhance productivity. From this point of view and consistent with our results, the selected emmer and spelt lines/cultivars studied in this work are characterized by a higher agronomic stability.

Table 6 and 7 show the results of the selective pressure imposed by the breeders to adjust the plant phenology (HD) of the modern lines/cultivars to southern Italian conditions, where early maturity permits drought escape. The effects of selection for PH was less evident although the differences among the accessions evaluated were significant. PH might be an important characteristic for organic farming since tall plants showed a higher competitiveness against weeds (without lodging effects due to low nitrogen availability). Indeed, the difference in $\mathrm{PH}$ between the new emmer and spelt cultivars/advanced breeding lines and their hulled parents was limited with mean $\mathrm{PH}$ values above $100 \mathrm{~cm}$ (Tab. 5 and 6).

The genotypes selected from emmer and spelt breeding programs showed a marked im- provement in PC, GC and GPY also when compared to durum and bread cultivars confirming that the special capability of hulled wheat to store large amounts of grain proteins (Galterio et al., 1994) was saved during selection of the new genotypes with a remarkable effect on GPY.

It is noteworthy that in low-input cropping system the adoption of the new emmer and spelt genotypes allowed to achieve a high PC that can easily satisfy the requirements of the industry. Beside yield potential, the TW was substantially enhanced by the selection with an effect more evident in emmer than in spelt probably because of the higher difference existing between tetraploid parents than between the hexaploid ones. TKW was also positively affected by the selection process as also previously reported by Fares et al. (2000) and Galterio et al. (2001).

\section{Conclusions}

The results of this study showed encouraging agronomic performances of new emmer and spelt genotypes under conventional and low-input cropping systems. The new genotypes are characterized by a yield potential similar to that of the modern wheat cultivar as well as by a PC higher than old emmer and spelt accessions. These results confirmed that it is possible to improve hulled wheat by introgressing useful traits from hulless wheat without loose the adaptability to low input conditions and the quality traits which represent the typical features of emmer and spelt.

\section{Acknowledgements}

This work was supported by the Italian Ministry of Agriculture, project SICERME and by EU COST action 860 (Susvar - Sustainable low-input cereal production: required varietal characteristics and crop diversity).

\section{References}

Becker H.C. 1981. Correlations among some statistical measures of phenotypic stability. Euphytica, 30:835840 .

Becker H.C., Leon J. 1988. Stability analysis in plant breeding. Plant Breed., 101:1-23. 
Bloom A.J. 1997. Nitrogen as a limiting factor: crop acquisition of ammonium and nitrate. In: Jackson L.E. (ed.): Ecology in Agriculture. Academic Press, San Diego, 145-172.

Campbell K.G. 1997. Spelt: agronomy, genetics and breeding. Plant Breed. Rev., 15:187-213.

Castagna R., Minoia C., Porfiri O., Rocchetti G. 1996. Nitrogen level and seeding rate effects on the performance of hulled wheats (Triticum monococcum L., T. dicoccum Schubler and T. spelta L.) evaluated in contrasting agronomic environments. J. Agron. Crop Sci., 176 (3):173-181.

Cubadda R., Marconi E. 1995. Technological and nutritional aspects in emmer and spelt. In: Podulosi S., Hammer K., Heller J. (eds.): Hulled Wheats. IPGRI, Rome, Italy, pp. 203-211.

Damania A.B., Hakim S., Moualla M.Y. 1992. Evaluation of variation in Triticum dicoccum for wheat improvement in stress environments. Hereditas, 116:163166.

Degaonkar A.M., Tamhankar S.A., Rao V.S. 2005. An assessment of cultivated emmer germplasm for gluten proteins polymorphism of gluten proteins in cultivated emmer germplasm. Euphytica, 145:49-55.

De Vita P., Riefolo C., Codianni P., Cattivelli L., Fares C. 2006. Agronomic and qualitative traits of $T$. turgidum ssp. dicoccum genotypes cultivated in Italy. Euphytica, 150:195-205.

Fares C., Schiavone M.G., Maddalena V., Trono P., Codianni P. 2000. Nuove linee di farro per sfarinati e pasta di qualità. Molini d'Italia, 4:37-41.

Fares C., Codianni P., Schiavone M.G., Di Fonzo N., Palumbo M., Virzì N. 2001. Caratteristiche agronomiche e merceologiche di varietà di frumento duro e frumento tenero adatte alla preparazione di prodotti da forno tipici dell'Italia Meridionale. Tecnica Molitoria, 9:936-938.

Finlay K.W., Wilkinson G.N. 1963. The analysis of adaptation in plantbreeding programme. Aust. J. Agric. Res. 14:742-754.

Galletti G.C., Bocchini P., D’Antuono L.F. 1996. Fiber composition of a neglected wheat species (Triticum dicoccum Schubler) as determined by pyrolysis/gas chromatography/mass spectrometry. J. Agr. Food Chem., 44:3133-3135.

Galterio G., Cappelloni M., Desiderio E., Pogna N.E. 1994. Genetic, tecnological and nutritional characteristics of three Italian populations of "farrum" (Triticum turgidum subsp. dicoccum). J. Genet. Breed., 48:391-398.

Galterio G., Codianni P., Novembre G., Saponaro C., Di Fonzo N., Pogna N.E. 1998. Storage protein composition and technological characteristics of $\mathrm{F}_{6}$ lines from the cross Triticum turgidum spp durum x Triticum turgidum spp dicoccum. In: Slinkard A.E. (ed.): Proceedings of the $9^{\text {th }}$ International Wheat Genetics Symposium, 2-7 August 1998, Saskatoon, Saskatchewan, Canada, Vol. 4, 148-150.
Galterio G., Codianni P., Giusti A.M., Pezzarossa B., Cannella C. 2000. Valutazione delle caratteristiche agronomiche e merceologiche di T. turgidum ssp dicoccum Schrank e T. spelta L. Nahrung/Food, 47:54-59.

Galterio G., Cardarilli D., Codianni P., Acquistucci R. 2001. Evaluation of chemical and technological characteristics of new lines of Triticum turgidum ssp. dicoccum Nahrung/Food, 4:263-266.

Galterio G., Codianni P., Giusti A.M., Pezzarossa B., Cannella C. 2003. Assessment of the agronomic and technological characteristics of Triticum tugidum ssp. dicoccum Schrank and T. spelta L. Nahrung/Food, 47:54-59.

Hoad S., Neuhoff D., Davies K. 2005. Field evaluation and selection of winter wheat for competitiveness against weeds. In: Lammerts van Bueren E.T., Goldringer I., Østergård H. (eds.): Proceedings of the COST SUSVAR/ECO-PB Work shop on Organic Plant Breeding Strategies and the Use of Molecular Markers. 103 pp. Driebergen, The Netherlands.

Köpke U. 2005. Crop ideotypes for organic cereal cropping systems. In: Lammerts van Bueren E.T., Goldringer I., Østergård H. (eds.): Proceedings of the COST SUSVAR/ECO-PB Work shop on Organic Plant Breeding Strategies and the Use of Molecular Markers. 103 pp. Driebergen, The Netherlands.

Laghetti G., Piergiovanni A.R., Volpe N., Perrino P. 1999. Agronomic performance of Triticum dicoccon Schrank and T. spelta L. accessions under southern Italian conditions. Agric. Med., 129:199-211.

L-Baeckström G., Hanell U., Svensson G. 2004. Baking quality of winter wheat grown in different cultivating systems, 1992-2001: A holistic approach. J. Sustainable Agr., 24:53-79.

López-Bellido L., López-Bellido R.J.,. Castillo J.E., López-Bellido F.J. 2000. Effects of Tillage, Crop Rotation, and Nitrogen Fertilization on Wheat under Rainfed Mediterranean Conditions. Agron. J., 92:1054-1063.

Marconi E., Carcea M., Schiavone M., Cubadda R. 2002. Spelt (Triticum spelta L.) pasta quality: Combined effect of flour properties and drying conditions. Cereal Chem., 79:634-639.

Mason H.E., Spaner D. 2006. Competitive ability of wheat in conventional and organic management systems: A review of the literature. Can. J. Plant Sci., 86:333-343.

Masri Z., Ryan J. 2006. Soil organic matter and related physical properties in a Mediterranean wheat-based rotation trial. Soil Tillage Res., 87:146-154.

Nass H.G., Ivany J.A., MacLeod J.A. 2003. Agronomic performance and quality of spring wheat and soybean cultivars under organic culture. American J. Alternative Agr., 18:164-170.

Nesbitt M., Samuel D. 1995. From staple crop to extinction? The archaeology and history of the hulled wheats. In: Podulosi S., Hammer K., Heller J. (eds.). Hulled Wheats. IPGRI, Rome, Italy, 40-99. 
Perrino P., Hammer K. 1984. The Farro: further information on its cultivation in Italy, utilization, and conservation. Genetica Agraria, 38:303-311.

Piergiovanni A.R., Volpe N. 2003. Capillary electrophoresis of gliadins as a tool in the discrimination and characterization of hulled wheats (Triticum dicoccon Schrank and T. spelta L.). Cereal Chem., 80 (3):269-273.

Pisante M., Basso B., Carafa A.C., Stornaiuolo S. 1996. To look forward to grow farro populations (Triticum dicoccumand T. spelta) under dryland environment in southern Italy. Riv. di Agron., 30 (2):147-153.

Ranhotra G.S., Gelroth J.A., Glaser B.K., Lorenz K.J. 1995. Baking and nutritional qualities of a speltwheat sample. Lebensm.-Wiss. Technol., 28:118-122.

Rodrigues M.A., Pereira A., Cabanas J.E., Dias L., Pires J., Arrobas M. 2006. Crops use-efficiency of nitrogen from manures permitted in organic farming Eur. J. Agron., 25:328-335.

Spiertz J.H.J. 1977. The influence of temperature and light intensity on grain growth in relation to the carbohydrate and nitrogen economy of the wheat plant. Netherlands J. Agr. Sci., 25:182-197.

Troccoli A., Codianni P., Ronga G., Gallo A., Di Fonzo
N. 1997. Agronomical performance among farro species and durum wheat in a drought-flat land environment of southern Italy. J. Agron. Crop Sci., 178:211-217.

Troccoli A., Codianni P. 2005. Appropriate seeding rate for einkorn, emmer, and spelt grown under rainfed condition in southern Italy. Eur. J. Agron., 22: 293-300.

van Lammerts Bueren E.T., Struik P.C., Jacobsen E. 2002. Ecological concepts in organic farming and their consequences for an organic crop ideotype. Netherlands J. Agric. Sci., 50:1-26.

van Lammerts Bueren E.T., Struik P.C., TiemensHulscher M., Jacobsen E. 2003. Concepts of intrinsic value and integrity of plants in organic plant breeding and propagation. Crop Sci., 43:1922-1929.

Wieser H. 2000. Comparative investigations of gluten proteins from different wheat species. Eur. Food Res. Technol., 211:262-268.

Winzeler H., Ruegger A. 1990. Dinkel: Renaissance einer alten Getreideart. Landwirtschaft Schweiz., 3:503.

Zadoks J.C., Chang T.T., Konzak C.F. 1974. A decimal code for the growth stages of cereals. Weed Res., 14:415-421. 